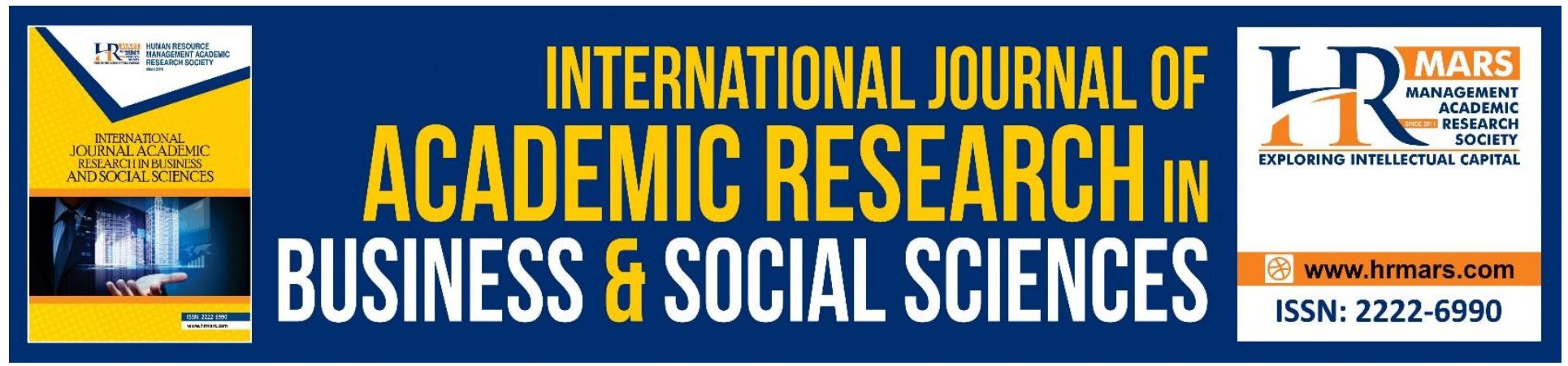

\title{
Emotional Intelligence (EI) among of College Student of Sultan Idris Education University (UPSI): One Construction and Personal Development through Tarbiyah Process
}

Syed Sofian Syed Salim, Md Amin Md Taff \& Hazriyanto

To Link this Article: http://dx.doi.org/10.6007/IJARBSS/v8-i9/4695

DOI: $\quad 10.6007 /$ IJARBSS/v8-i9/4695

Received: 10 August 2018, Revised: 25 August 2018, Accepted: 29 Sept 2018

Published Online: 15 October 2018

In-Text Citation: (Salim, Taff, \& Hazriyanto, 2018)

To Cite this Article: Salim, S. S. S., Taff, M. A. M., \& Hazriyanto. (2018). Emotional Intelligence (El) among of College Student of Sultan Idris Education University (UPSI): One Construction and Personal Development through Tarbiyah Process. International Journal of Academic Research in Business and Social Sciences, 8(9), 1256-1266.

Copyright: (C) 2018 The Author(s)

Published by Human Resource Management Academic Research Society (www.hrmars.com)

This article is published under the Creative Commons Attribution (CC BY 4.0) license. Anyone may reproduce, distribute, translate and create derivative works of this article (for both commercial and non-commercial purposes), subject to full attribution to the original publication and authors. The full terms of this license may be seen at: http://creativecommons.org/licences/by/4.0/legalcode

Vol. 8, No. 9, September 2018, Pg. 1256 - 1266

Full Terms \& Conditions of access and use can be found at http://hrmars.com/index.php/pages/detail/publication-ethics 


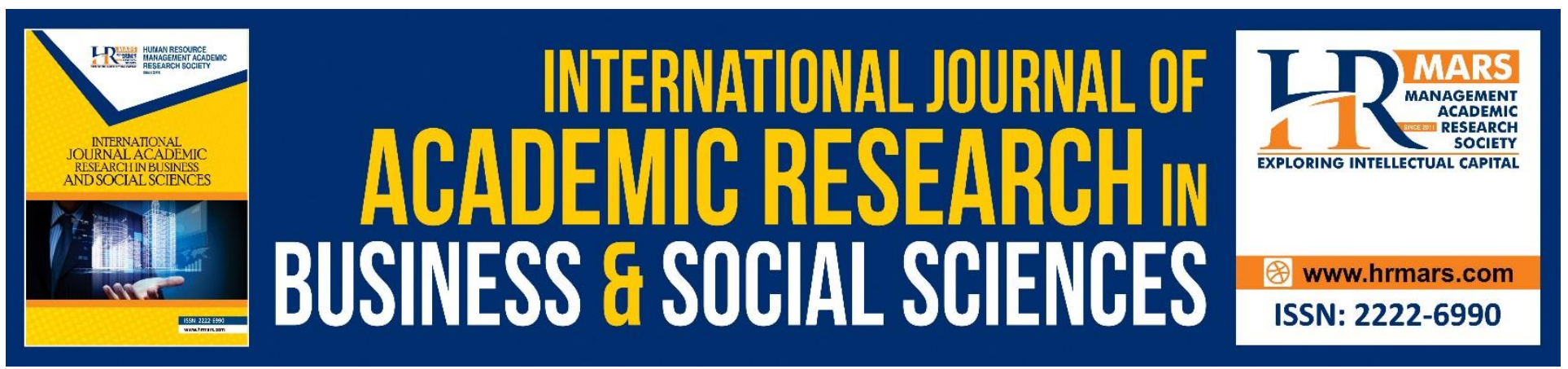

\title{
Emotional Intelligence (EI) among of College Student of Sultan Idris Education University (UPSI): One Construction and Personal Development through Tarbiyah Process
}

\author{
Syed Sofian Syed Salim¹, Md Amin Md Taff ${ }^{2} \&$ Hazriyanto $^{3}$ \\ ${ }^{1}$ Faculty of Education and Human Development, Sultan Idris Education University, Tanjong Malim, \\ Perak, Malaysia \\ ${ }^{2}$ Faculty of Sports Science and Coaching, Sultan Idris Education University, Tanjong Malim, Perak, \\ Malaysia \\ ${ }^{3}$ Faculty of Economics and Management, STIE Galileo, Batam, Indonesia
}

\begin{abstract}
The importance of Emotional Intelligence (EI) is undeniable in determining one's achievement to succeed in all aspects of life, especially among college students and university. Plato once revealed that 'emotions are only owned by humans'. When emotions are owned by humans, humans are constantly changing according to the 'mood' changes in everyday life which affects one's personality and personality which ultimately affects position and friendly relationships between individuals in their social, career or organizational environment. Many studies prove that one's success is closely related to the elements in El as motivated, confident, able to focus, excellence, have strong motivation to learn and work in groups and skills in communicating. According to Goleman (1995) in his book 'The Emotional Intelligence', an individual's assessment is not only based on Intellectual Quotient (IQ) but more importantly is the El that is owned. Next, good El will assist in self-motivating, strengthening endurance in the face of all forms of failure, controlling emotions, maintaining the state of the soul and being capable of producing a praiseworthy and mature leadership. The study by Martinez (1997) finds that El has a strong correlation with the improvement of personality, satisfaction in life and outstanding achievement in their career and social. Therefore, this paper will try to deliberately discuss how the role of El can be expected and applied in forming and producing commendable and outstanding qualities among university / college students and colleges in line with the concept and process of tarbiyah in itself based on Goleman Mixed Model (Goleman, 1998) as well as suggestions on the guidance or strategies towards the formation of the commendable and excellent personalities of the university and colleges.
\end{abstract}


INTERNATIONAL JOURNAL OF ACADEMIC RESEARCH IN BUSINESS AND SOCIAL SCIENCES

Vol. 8, No. 9, Sept. 2018, E-ISSN: 2222-6990 @ 2018 HRMARS

Keywords: Emotion, Wisdom of Emotion, Citizen, Mood, Intellectual, Tarbiyah

\section{Introduction}

During this time El was underestimated and deserted by researchers. Researchers, even including parents, only view El as a very important and highly respected aspect. Therefore they are trying to improve the ability of their children. In fact, parents are sending their children in various motivational courses for the enhancement of their children's IQ so that the EI and spiritual Intelligence (SI) are ignored. Not only in modern medicine and Islam many medicines and supplements appear for the purpose of improving an individual's IQ.

The study of human IQ, too much is done by researchers. However, since the term El was used in the 1990s by Peter Salovey and John Mayer, this El has started to get attention. This is because they think El can be used to explain the qualities of self and leadership, especially in emotions so that one can achieve success especially in social life and organization. This is in line with the meaning of tarbiyah concept in Islam as discussed in Manhaj Tarbiyah 'Inda Al Ikhwan Al Muslimin's book written by Dr. Abdul Halim Mahmud is the former Syeikh of Al Azhar University. According to him, tarbiyah is 'an ideal way of interacting with human nature, either directly through words or indirectly in the form of exemplary, in accordance with the specific system and rank that is believed, to process changes in human beings to a better condition'.

Here it is clear that the tarbiyah islamiyah is the process of completion of the pious man, which featured gather around a balance in one's human potential, purpose, speeches and actions as a whole. So in conclusion the human balance can be formed in the stage-by-stage in many ways because it was not born with genetics. All these processes will lead to construction and development to better high and perfect if planned properly and smoothly from the start human growth.

\section{Methodology}

Many students assume co-curricular activities are not important and are wasting time because they are not assessed as academically relevant activities. Today students are very concerned about the exams so that co-curricular activities are also part of the learning process. The involvement of students in co-curricular activities especially in local universities is no longer based on the spirit of willingness or volunteerism. Most students get involved just to get some rewards whether to stay in college or to get awards introduced by their respective universities or national level. There are even universities that mandatory have to set the obligations of students to engage in co-curricular activities to expose their students in acquiring soft skills that are appropriate to the job requirements after their students graduate.

Based on a study conducted by the National Economic Action Council (2005), out of 12 criteria listed by 115 employers in an unemployment survey conducted, one of the top three criteria listed by the employer is good communication skills while academic achievement is in the eighth position (Marlina, 2005). 
Adham Baba (The Daily Stories, 2004) stating that the public and private sectors now require graduates who are capable of communicating, mastering multiple languages, critical thinking, being able to work in teams and possess leadership qualities in which they can only be acquired through engagement in co-curriculum activities and all of these are directly related to the El dimensions.

\section{Literature Review}

\section{a. Emotional Intelligence}

The word emotion comes from the Latin word motere which means moving, in which each emotion is capable of seeing and happening involving feelings of excitement, annoyance, affection, hatred, fear, jealousy, excitement or impairment of feelings and so forth (Goleman, 1995 ). It is a strong feeling in the interior of man. It involves mental or instinctual aspects such as love or fear.

In short, emotions experienced by one person will affect and affect the whole life of a person either psychologically or in social life. Therefore, emotion is a process that directs or destroys the behavior that comes from internal feelings.

Intelligence is also the mental ability of a man to achieve what he wants.

According to Chaplin (1981) intelligence can be summarized into three aspects where it has an equation in terms of: -

a. The ability to confront and adapt to the new situation quickly and effectively.

b. Ability to use the abstract concept effectively which includes three elements such as understanding, giving opinions and criticizing.

c. Ability to understand the relationships and learning process quickly and rapidly.

Thus overall intelligence is more about the capabilities shown and owned by an individual in the face of a situation. Based on this statement it can be concluded that every human being has the different capabilities in handling and managing their emotions. This ability and ability will determine the level of intellectual maturity, emotional well-being and personal development of an individual. Therefore, the individual who is capable or able to use the dimensions of the feeling that is in him and cares for others is an individual who is said to have high quality in El

\section{b. Emotional Intelligence And Co-curriculum}

According to the National Education Philosophy (FPN), in order to produce balanced students in physical, emotional, spiritual, intellectual and social aspects, co-curriculum can contribute to producing balanced learners from all aspects. In this context it is the role of co-curriculum as complementary to the curriculum in its role which can be obtained outside the classroom or inside classroom. Through the purely curriculum it is difficult for an educational institution to produce perfectly balanced individuals. IQ can be developed through the curriculum but El is rather difficult to develop through the curriculum. It is more easily developed and enhanced only through cocurriculum. 
$\mathrm{IQ}$ is important in determining the success of a student in the learning environment, but El is more important in determining the success of a person after school in real life and real life. This is in line with Goleman's statement, that 80 percent of a person's success in life, society or organization is related to $\mathrm{EI}$, while 20 percent only involves IQ.

In terms of leadership and social development it clearly shows that involvement in all cocurriculum activities can contribute to the formation of a leader and a socially competent human being. Leadership process is formed when a leader is able to navigate a well-organized group or person (Gary, 2001). In the context of co-curriculum, leadership skills are the aspects that are applied when involving external work activities that require a leader among students to be the leader to ensure that the activities are carried out smoothly and successfully. This opinion is supported by Helen (2001) stating that through the involvement in co-curricular activities, an individual is able to lead as it has been organized and has certain goals to be achieved.

It is clear that co-curriculum activities can provide early training in terms of leadership, personality and social ties among students. Leadership can be trained through uniforms, associations, clubs, cultures, religions and sports activities. This shows that the involvement of student in cocurricular activities will improve and solidify the KE student.

All that is discussed clearly is related to the dimensions found in El that can produce balanced, mature, skilled, easy social, able to control emotion and great leadership. This indicates that El can be improved from time to time by encouraging participation in all co-curricular activities to university or college students.

\section{Goleman Mixed Model}

Goleman (1998) states El is an important aspect in predicting and determining the happiness and success of an individual at home, at work and so on. In fact, 80 percent of the people's success is helped by El. Instead, IQ contributes only 20 percent or maybe less. For him El is a person's ability to recognize the feelings of others, others, can motivate themselves and can also manage their own emotions well in interacting with others in their surroundings.

The El mix model introduced by Goleman is chosen because it is appropriate in all aspects of the author's study and discussion. It is not only suitable for students, leaders, all workers of high rank or lower rank, but also suitable and applicable to all occupations and target groups. Boyatzis, Goleman \& Hay/McBer (1999) argues, this Goleman mix El model can be applied to all types of work, human beings and the background of life. Due to this suitability, researchers consider that this model can be applied to university / college students in all fields they take at university.

This Goleman mix model has several clusters of companions which focus on talents and human-specific abilities which can predict and determine one's success. Through this El Goleman model, he subsequently produced two major models of original models and models that have been renewed. But both models are not much different. At its original level, its model was broken down 
INTERNATIONAL JOURNAL OF ACADEMIC RESEARCH IN BUSINESS AND SOCIAL SCIENCES

Vol. 8, No. 9, Sept. 2018, E-ISSN: 2222-6990 (C) 2018 HRMARS

into five components and when it was redesigned and renewed it was reduced to four components. But both did not show a clear distinction.

In addition, the model introduced by Goleman also has similarities with other models as suggested by Salovey and Mayer and Bar-On, which Goleman has made some adjustments with the aim of facilitating understanding and conformity.

\section{Table 1: Goleman Mix Emotional Intelligence Model (Original)}

\begin{tabular}{ll}
\hline \multicolumn{2}{c}{ Goleman's Five Dimensional Disclosure } \\
\hline 1. Recognize Emotions & 4. Recognize Emotions Of Others \\
- Emotional Awareness & - Empathy \\
- The acuuracy of self assessment & - Organizational Awareness \\
& - Service Orientation \\
2. Managing Emotion & - Lelps Others \\
- Self Control & Looks for the difference \\
- Trust & Builds Realtionship with others \\
- Prudence & - Leadership \\
- Adjustment & - Influence \\
- Innovation & - The catalyst for change \\
3. Self Motivation & - Management conflict \\
- Achievement Orientation & - Collaborate \\
- Commitment & - Group ability \\
- Initiative & \\
\hline
\end{tabular}

Source: Goleman (1998)

Table 2: Goleman Mixed Emotional Intelligence Model (New)

Goleman's Fourth Dimension of Intelligence

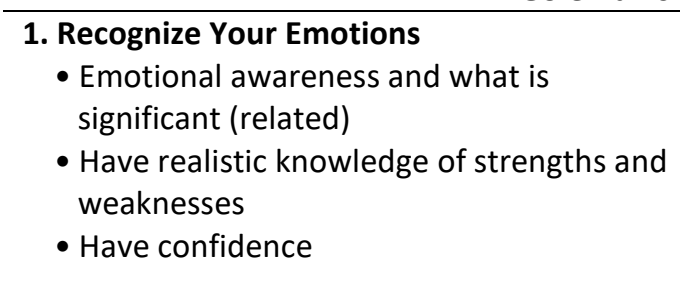

\section{Social Effectiveness}

- Empathy

- Sensitive and sensitive to group dynamics and between group

- Focus on needs

2. Self-Management

- Emotional control

- Trust and prudence

- Flexible and dedicated
4. Social skills

- Help others

- Effective leadership

- Change of management skills

- Ability to resolve debate and dispute

- Skill influencing

- Interpersonal communication skills

- Ability to nourish and build good Relationship

- Teamwork and teamwork skills 
INTERNATIONAL JOURNAL OF ACADEMIC RESEARCH IN BUSINESS AND SOCIAL SCIENCES Vol. 8, No. 9, Sept. 2018, E-ISSN: 2222-6990 @ 2018 HRMARS

In his El Goleman model (originally) he discussed the five main dimensions which in the first three dimensions discuss about the individual's own self. While in the next two dimensions he discusses the external aspects of the individual, which are related to aspects of social relationships.

In his first dimension he talked about the need of an individual to recognize his own emotions. This is important where it can help a person in preparing for any situation and difficulty. Bila seseorang telah dapat mengenai emosinya sendiri ia akan membantu seseorang dalam pengurusan diri mereka sendiri dengan baik dan berkesan.

For Goleman someone with high El will be able to manage themselves effectively. This is because they can control their emotions to be channeled at the right time and place.

The third dimension that involves in the individual itself is the ability to motivate oneself or to push himself to do something. Goleman in this dimension has included several other relevant elements of achievement orientation, commitment, initiative and optimism.

The fourth dimension is related to the social skills possessed by someone who has a high El. The ability to recognize the emotions of others can help in building a positive and effective relationship. Pool (1977) states, a person who has a high EI and social relationships well will gain a social connection full of fun, enjoyment and joy.

The last dimension of the fifth being discussed is the ability to build social relationships with others. This ability should involve some of the key aspects of leadership, communication, ability to influence, manage and resolve conflicts, work together and be capable of group work. In building a good and effective social relationship, one needs to be able to read all oral and non-verbal references (Pool 1997).

For the edition of the new Goleman mix El model, he has reduced his dimensions to just four dimensions. The four dimensions are two that involve the dimension of the individual itself which involves emotion and the other two are related to social skills.

In his first dimension he still talks about the need to recognize his own emotions. In this dimension he divides this dimension into three related sub-dimensions, the first is emotional awareness and what is significant, the second is to have realistic knowledge of the strengths and weaknesses of the self and the third is the need for self-confidence. The second dimension is related to self-management and divided into three sub-dimensions, the first is related to emotional control, the second is trust and prudence, and finally the third is related to the flexible and dedication aspect.

For dimensions involving social relationships, Goleman has incorporated the dimensions of social efficiency in the third dimension. Sub-dimensions for social efficiency are divided into three sub-categories: (i) empathy, (ii) sensitive and sensitive to group and group dynamics and (iii) focus on groups and other people's needs. While for the fourth and final dimensions of social relations, 
Goleman has incorporated social elementary skills in which there are eight sub-dimensions in this section: (i) helping others, (ii) effective leadership, (iii) changing management skills, (iv) the ability to resolve debates and conflicts, (v) influencing skills, (vi) ability to nourish and build good relationships, and ultimately (vii) collaborative and group skills.

As a result of both Mixed model has inspired Goleman and a clear picture of the author build a new model that can be adopted and adapted to the social and cultural environment of undergraduate college student locally in Malaysia.

\section{Tarbiyah PuEi ${ }^{5} \mathrm{D}$ Model}

Goleman (1998) says to is an important aspect in the forecast and determine an individual's happiness and success both at home, in organization, at work and so on. For him, the ability to recognize someone in feeling yourself, other people, able to motivate yourself and can also organize your own emotional well in interacting with others in the surroundings. Based on dimensions and statements of Goleman author has developed an appropriate model in building and improving into undergraduates students of colleges and universities.

\section{PUEI ${ }^{5}$ D TARBIYAH MODEL: IMPROVEMENT TO STUDENTS Of COLLEGES AND UNIVERSITIES BASED ON MIXED MODEL GOLEMAN}

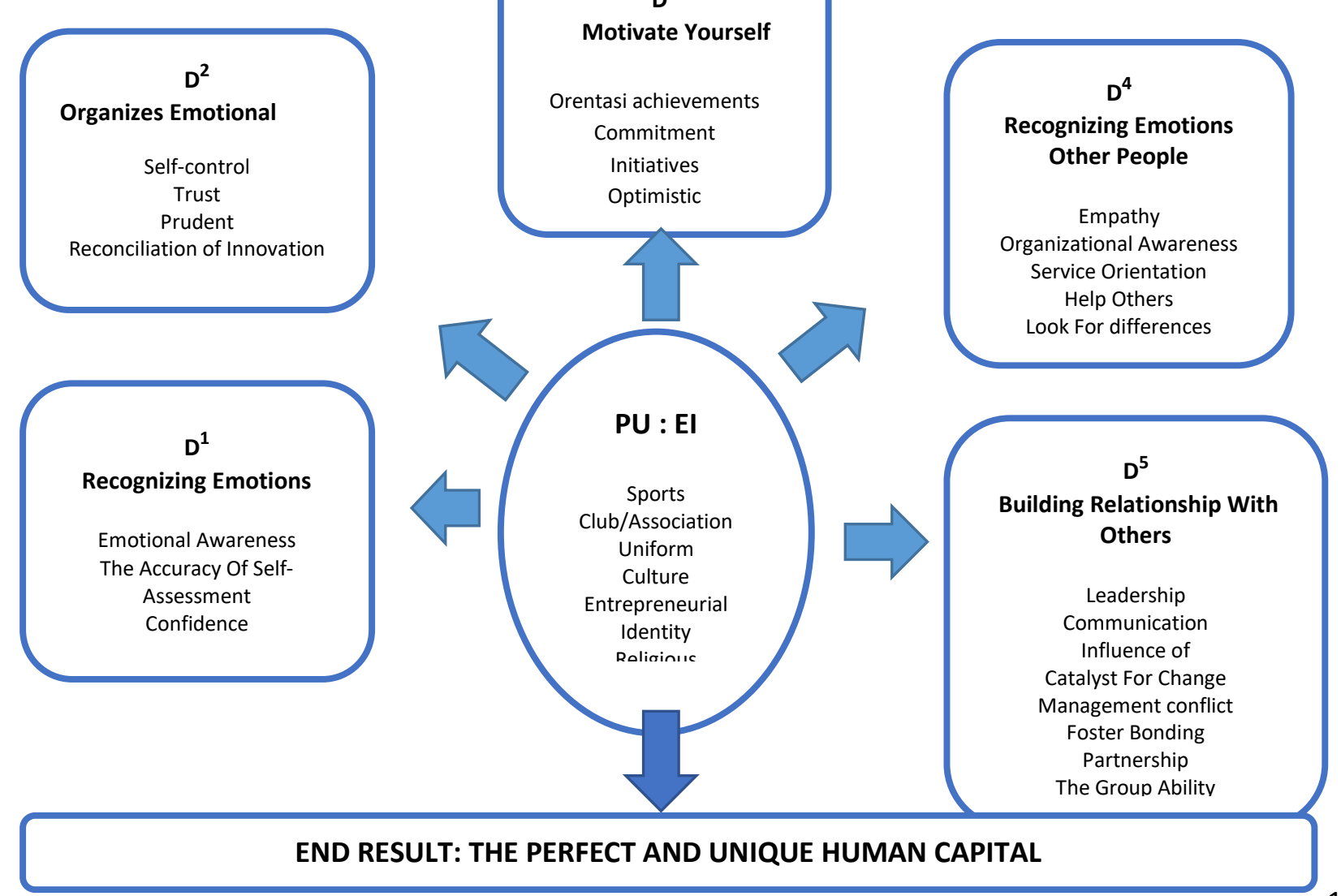


INTERNATIONAL JOURNAL OF ACADEMIC RESEARCH IN BUSINESS AND SOCIAL SCIENCES

Vol. 8, No. 9, Sept. 2018, E-ISSN: 2222-6990 @ 2018 HRMARS

\section{Guidelines and Strategy Tarbiyah PuEi ${ }^{5} \mathrm{D}$}

Following below are recommended steps and guidance to produce higher level El student. Among them are;

1. To conduct activities which includes all elements inside.

2. Each semester compulsory student involved a minimum of at least one activity of Association, sports and others.

3. The student is obliged to at least hold a position at the University or college.

4. Only students meet certain criteria are allowed to live in the College or hostel

5. Student are not allow to graduate if they do not meet the criteria set by the curriculum of the University.

6. conduct appropriate system for students to view the adequacy or monitor own their participation in each of the prescribed activities.

7. Participation in activities should be recorded in each semester examination result slip.

8. The credit value of extra-curricular involvement were noted in the score or even degree they earn.

\section{Discussion}

Based on the model of PuEi ${ }^{5} \mathrm{D}$ modified by Goleman model, it is clear to us that role to increase the level to students is located in the hands of the parties from the individual self or the University itself. Emphasis and disclosure to extra-curricular activities should be explained to students will be of its interest in shaping the development of solf skill, leadership as well as to them. The amount of credit and special privileges should be given to those involved in all the planning in curriculum. It's very important to make it compulsory for all students both male and female involved. Although this show a form of compulsion and mandatory but it will benefit directly and indirectly to students especially after they graduate later.

Given that the development stage of El is not affected by genetic or inherited factors, El can be enhanced with planned. The university should force all students either living in college or off campus to engage in co-curricular activities. Co-curriculum activity can provide early training in terms of leadership, personality and community among students. Leadership can be trained through all activities available at universities or colleges such as uniforms, associations, clubs and sports. This clearly demonstrates that all leadership-related issues arise from the development of El resulting from the involvement of students in all co-curricular activities at colleges or universities.

It is therefore concluded that El plays a crucial role in shaping leadership development and all human life of a student. This is in line with the study conducted by Deborah (2002) which also states that leadership features can be applied through outside activities of class or lecture hall.All of these discussions are directly and indirectly related to El dimensions as found in the new PuEi $\mathrm{D}^{5}$ model formed and presented by researchers 


\section{Summary}

It can therefore be concluded that El plays a vital role in shaping the development in all aspects of life which can be achieved through the role of the individual itself in his ability to know his emotions, to manage his own emotions, and to motivate himself. In addition, individuals with high El can also recognize the emotions of others in their environment, especially in an organized environment and can also build a good and comfortable relationship with others in their organization environment. Hence this will create a situation in social relationships and to create a harmonious communication process at all levels and to help overcome stress problems at work and ultimately lead to increased productivity of the self, organization and feel the satisfaction of satisfaction in whatever they do (Syed Sofian et al., 2012).

Most of the studies done clearly show that when El high, one will be more involved and successful in all areas involved. This is in line with Goleman's (1995) opinion that 80 percent of the individual's success is determined by El compared to IQ which contributes only 20 percent. Yet all this depends and lies directly on the determination and willingness of a person in the full involvement of whatever field they belong to either in association or in the career they have chosen. In addition, Goleman (1998) in his theoretical framework also thinks that one's excellence in his organization environment depends on his ability to use the emotional aspects of his El. This demonstrates the emotional efficiency of the self-management and self-motivation in directing individual statements or intuition towards achieving a goal.

Therefore, with this goal directly people with intelligent emotions will show an increase in the achievement, involvement and effort of a person in all fields involved. The higher the person is, the higher the person's loyalty to the work and the organization. This can be demonstrated by their unwavering involvement of all efforts that bring progress in the aspects of leadership, careers and organizations. This situation will further enhance the sense of citizenship and love for the work and organization it comprises (Mohd Azhar 2004). This is in line with the study conducted by Syed Sofian et. al. (2012) clearly demonstrates that individuals with high or moderate El will be great leaders because they can recognize themselves and others emotionally, manage their emotions accurately, possess good social skills and competence as well as acceptable to members in their organization environment.

\section{Corresponding Author}

Name : $\quad$ Associate Professor Dr Syed Sofian Syed Salim

Affiliation: Sultan Idris Education University

Country: Malaysia

Email ID : $\quad$ sofian@fpm.upsi.edu.my

Address : $\quad$ Faculty of Education and Human Development, Sultan Idris Education University 35900 Tanjong Malim, Perak

\section{References}

Berita Harian. (2004, April 4). The mission of UTHM is to create balanced students. 10. 
INTERNATIONAL JOURNAL OF ACADEMIC RESEARCH IN BUSINESS AND SOCIAL SCIENCES

Vol. 8, No. 9, Sept. 2018, E-ISSN: 2222-6990 (C) 2018 HRMARS

Boyatzis, R.E., Goleman, D., \& Hay/McBer. (1999). Emotional competence Inventory. Boston: Hay/McBer Group.

Chaplin, J.P. (1981). Dictionary of Psychology. New York: Dell Publishing Company.

Deborah, H. (2002). Guiding Corporate Behaviour : A Leadership Obligation, Not a Choice. Volume 1, 15-19.

Gary, Y. (2001). Leadership In Organizations. Retrieved from http://www.ncsl.org.uk/media-F7B-97randdleaders-business-yukl.pdf.

Goleman, D. (1995). Emotional intelligence: Why it can matter more than IQ. New York: Bantam Books.

Goleman, D. (1998). Working With Emotional Intelligence. New York: Bantam Books.

Helen, M.G. (2001). Leaders and Leadership in Education. London : Paul Chapman Publishing.

Majlis, T.E.N. (MTEN). (2005). Graduate Enrollment Unemployed and Employment among Graduate. Malaysia.

Marlina, A. (2005). Critical Thinking Skill Mastery Level among Physics Education Students at Universiti Teknologi Malaysia. Masters Thesis. Universiti Teknologi Malaysia, Johor, Malaysia.

Martinez, P. (1997). The relation of emotional intelligence with selected areas of personal functioning. Imagination, Cognition and Personality, 17 (1), 3-13.

Mohd, A.H.Y. (2004). The effect of emotional intelligence on job commitment, organizational commitment, job satisfaction and organizational citizenship behavior. Ph.D Thesis. Universiti Kebangsaan Malaysia.

Pool, C.R. (1977). Up with emotional health. Educational Leadership, 55, 12-14.

Syed, S.S.S., Rohany, N., Mohammad, A.S.M.A., \& Muhammad, B.M. (2012). The role of emotional intelligence on job satisfaction among school teachers. The Social Sciences, 7(1), 125-129. 